\title{
An analytical framework for the firm
}

\author{
W. Herbst
}

Many theories to cope with the increasing sophistication and complexity of business organization have been developed. An overview is given of the games theory approach to strategy, the capital investment approach and the product-market approach. The product-market approach is described as a useful management tool since it takes into consideration the ever-changing relationship between the enterprise and its environment, in the analysis of both the present operations of the firm, and its future activities. The enterprise must be seen as an integrated system, and its interactions with the environment planned and implemented in terms of policy commitments or strategic variables that are clearly formulated. This strategic approach to management could promote both the commitment and the competence of the firm's personnel.

S. Atr. J. Bus. Mgmt 1979, 10: 37-40

Verskeie nuwe bestuursteorieë om die toenemende sofistikasie en kompleksiteit van die sake-onderneming te kan behartig, is ontwikkel. 'n Oorsig word gegee van verskillende bestuursbenaderings tot strategie, dié gebaseer op spel-teorie, op kapitaal-investering en op produk-markontleding. Die produk-mark benadering word beskryf as 'n nuttige bestuurshulpmiddel wat die steeds veranderende verhouding tussen die onderneming en sy omgewing in die ontleding van sowel die huidige bedrywighede as die toekomstige aktiwiteite van die onderneming in aanmerking neem. Die onderneming moet as 'n geïntegreerde sisteem gesien word, en wisselwerking met die omgewing moet beplan en geïmplementeer word volgens beleidvasstellings of strategiese veranderlikes wat duidelik geformuleer is. Hierdie strategiese benadering tot bestuur kan sowel die motivering as die prestasie-vermoëns van die onderneming se personeel bevorder.

S.-Afr. Tydskr. BedrytsI. 1979, 10: 37-40
Since the introduction of the profit maximization concept or the micro-economic theory of the firm, many new concepts have been advanced for improving management, these ranging from organization theory, decision theory and planning theory to the so-called behavioural theory of the firm. ${ }^{1}$

The latter approach criticized the traditional theory of profit maximization on the grounds that the micro-economic analysis has little bearing on the decision-making process of a firm.

There were other factors that also caused the need for a more sophisticated theory of the firm:

- Technological development led to the shortening of the life cycle of products and increased the risk of product substitution.

- Increased competition did not only cause lower profit margins, but new product development and intrusion upon traditional products and markets also emphasized the importance of capital investment planning.

- The acceleration and expansion of economic growth since World War II created new opportunities for investment.

- The establishment of the large scale enterprise promoted the decentralization of activities and management. Decentralization in turn emphasized the need for improved methods of planning and control.

- The institutionalization of savings and investments necessitated a professional approach to the investment of funds and analytical methods for the evaluation of enterprises, and investment in those enterprises ensured the effective application of funds.

- The effect of taxation and the possible change in tax rates emphasized the importance of debt capital with its leverage effect.

- The problem of inflation and instability of exchange rates complicated the estimation of production costs.

- Changes in the international business field also played an important part in the development of new theories and approaches.

\section{The Theory of Games}

In 1947 Von Neumann \& Morgenstern's work, Theory of games and economic behaviour ${ }^{2}$ was published. In the theory of games, strategy is described as a complete plan that indicates for every possible situation in the military, 
political or operational sphere and for every available composition of information within the cadre of the rules of the game, what decision the player considers to take.

The definition of strategy as derived from the games theory is inadequate since it is impossible to predetermine all alternative situations in the enterprise. The theory of games, however, gave rise to new ways of thinking and to the increased use of the strategy concept.

In the military sphere strategy is an age old concept. Beishline ${ }^{3}$ defines strategy as follows: 'A declaration of war is a formulated policy; the decision to carry on war by means of an attack upon certain mountain passes, parts or oil fields is strategy; and the method of attack which uses a sequence consisting of planes, tanks and infantry supported by artillery, is an example of tactics'. Tactics can be seen in context as the application of resources towards improvement of the competitive position in order to attain advantageous goals.

The function of strategy in the military sphere therefore is very similar to that in the business sphere.

The so-called theory of the firm is also applicable here. In a firm profit maximization is the goal that is attained in the maximization of the company's net present value, the maximization of the market value of the firm, or the restricted profit maximization due to expansion. All these approaches are known as the capital investment theory.

The main criticism against this theory is that the strategic problem falls beyond the limits of micro-economics.

The product-market investment approach is proposed as an alternative. This approach is a systems approach that emphasizes inter alia the human behavioural aspects in the organization and a view of the firm as an integrated system, interacting with its environment.

It may be advisable to compare the two approaches.

\section{The Capital Investment Approach}

In the capital investment approach the strategic plan is shown in the form of a budget, with projected assets and liabilities at some future point in time, together with the anticipated income and expenditure between the present and the future dates. Distinctions are made between long-term and short-term forecasts. The former, generally for a period of five years or more, are those with which business strategy is especially concerned. The identification and enumeration of fixed asset and equipment proposals for the budget period are therefore the starting point of the capital investment theory. Profitability is evaluated by computing the value of net revenues which will flow specifically from the utilization of each of these assets. All possible asset situations are studied, and those showing the greatest return on capital employed are chosen. In this way the selection of the markets to be entered and the products to be manufactured is automatically accomplished.

Most methods apply discounting - an acceptable and necessary consideration - but it really only takes care of variations in the timing of cash transactions, leaving out of account the fact that the size of future transactions to which the discount rate is applied is of far greater importance. Cash flow data for more complex situations become a valuable part of the analysis, and must be combined with factors for which quantification is far more difficult.

The capital investment theory is characterized by the following premises:

- Long-term profitability over the lifetime of the project is used as the yardstick for evaluation.

It is assumed that profit is the sole objective of a firm.

- It is assumed that all of the decision alternatives can be enumerated and their outcome measured.

- The longer the period involved, the more unrealiable are the cashflows used in evaluating the available data.

- All alternatives must be known at decision time.

- The problem of risk is generally ignored in most methods of computing profitability, or is handled very superficially.

- The joint effects of new project introduction are not considered.

- The strategic plan produced is explicit but not viable, so that it is difficult for the enterprise to maintain its selfdirecting initiative.

\section{The Product-Market Approach}

The product-market approach to strategic decisions views the organization as a network of members operating an aggregate of resources within a competitive environment. ${ }^{4}$ Corporate success, therefore, depends on the organization using its distinguishing characteristics to the very best advantage. This involves recognition, at any and every point of time, of the organization's distinguishing characteristics, of its present strengths and weaknesses and of its probable future strengths and weaknesses. As experience has repeatedly demonstrated, conditions change and competitors become forces with which to contend. Hence an extension of past strategy is essentially a negative force.

For these reasons the requirements of and opportunities within the environment must be immediately recognized and acted upon. In this respect a definition of the company's scope must be clearly formulated, in terms of the markets and customers served, the characteristics of products or services, and the sales mix as the basis on which the company has chosen to compete. Such a definition affords the company an opportunity to establish a distinctive competence, which will give it a unique competitive advantage. This method, of clearly defining the company's scope relative to its environment, is a strong basis of the productmarket approach.

The deployment of the company's resources indicates the emphasis and priorities placed upon various operations. In planning, therefore, the decisions taken on the deployment of the company's future resources become the final commitment on the path of future strategy.

The greatest application of the product-market approach, after the present situation is clearly understood, is planning the future activities of the enterprise. This approach allows the enterprise to determine and alter events; to actively initiate upon its environment, rather than allowing itself to be shaped by external factors over which it exercises no control.

The definition of the company's scope and present deployment of resources must be followed by a definition of where the company wants to go and what it wants to be. The more explicit it makes this definition of strategy, the clearer will be the choices and their consequences, as the company responds to and initiates upon the environment in which it operates.

Therefore, by using the product-market approach, the company can specify its desired future size and market share, its profit expectations, its life expectancy characteristics and the deployment of resources required to reach these objectives. 
All these definitions bring us to the question of what the product-market approach signifies, and to the usefulness of this approach as a management tool.

This approach may be summarized as follows:

- It diagnoses the need for strategic action by analysing the trends in the return on investment and the rate of growth.

- It recognizes when the time has arrived to diversify by picking up adverse trends in return on investment and rate of growth.

- It takes account of the fact that a business has a vector of interests, usually composed of conflicting objectives, and only one of which is profit.

- It takes account of the joint effects produced by the existing projects and the new project.

- It examines the strategy which brought the company its success in the past and considers which of those past methods may be obsolete and inappropriate in a changing world.

- It takes cognizance of the fact that an enterprise has a network of members as one of its component parts, and decides which values of membership are to be emphasized and pursued.

\section{The Product-Market Approach as a Management Tool}

Now we come to the usefulness of this approach as a management tool. It is interesting to note that one-man businesses, partnerships and small limited liability companies have all along, consciously or unconsciously, subscribed to management of the total enterprise or have followed the product-market approach. In any case, their type of business did not lend itself to the adoption of the functional approach.

On the other hand, there are firms which have outgrown their infantile status by internal growth and/or by a series of mergers and acquisitions. This expansion in their scale of operations often leads to the adoption of a functional approach.

Here the problem of managing the firm is divided into its component elements in order to make it manageable. In other words, the problems are accorded a 'functional classification' and, when applied to business activity, there is a tendency to approach a problem in isolation rather than in terms of the business as a whole. This approach rests on the premise that the different departments of an enterprise function independently, enjoying a certain amount of individuality and autonomy and, consequently that problems in each of the functional areas are also dealt with separately without regard to the reaction from other functional areas.

'In contrast to the elemental (or functional) frame of reference, so enormously useful when dealing with specified parts of a whole, a different way of thinking is required when one deals with the total, unified, interacting, interdependent systemic character of a business enterprise. ${ }^{\prime}, p, 16$ The emphasis here is on the 'totality' of the enterprise with each person becoming deeply involved in the system. His actions are determined by certain aspects in the system. Similarly, the system as a whole is also affected by his behaviour and by the behaviour of the environment.

Thus, the functional approach is well suited to specialized functions, whereas the systemic approach is allied to total enterprise management. If a choice is to be made between the two systems, it would be difficult to exclude any one system. Both systems can, however, be utilized: the functio- nal approach being applied to those problems which can be separated and clearly defined, and the systemic approach to those which cannot be isolated. The functional or elemental approach helps to keep the variables so low that problems become more manageable. On the other hand, the systemic view prescribes a maximum number of variables for consideration so that a combination is found which promises to yield the best return from the available resources.

Closely associated with this functional and systemic approach is the fact that every major function of a business (production, sales, research and development, etc.) has its own unique values and criteria and that each department sets a goal that could be unrelated to a company's objectives and performance criteria. For example, a production manager aims at reducing cost and raising internal operating efficiency, whereas the sales department will tend to put the greatest emphasis on increasing sales volume or market share. So each department formulates its own set of criteria without regard to the criteria set by others.

These departmental criteria are indeed desirable since each has advantages for the welfare of the enterprise. But the greatest drawback is that these criteria can seldom be satisfied simultaneously. Hence the need for a general management point of view 'which seeks a balanced equilibrium among conflicting aims'. ${ }^{4, p}{ }^{18}$ Foremost in strategic decision-making should be the over-all corporate goals.

The question thus arises: how can these over-all goals be met?

Robert L. Katz ${ }^{4, p}{ }^{20}$ describes the enterprise's over-all situation in terms of these separable but related dynamic variables.

These are the business's environment, resources and members. He views the enterprise as being composed of:

- A network of members who possess differing types and degrees of competence and skill, differing values, personal goals and commitments, differing degrees of interpersonal contact, co-operation and influence.

- These members have available to them an aggregation of resources in the form of capital, production and service facilities in a market and/or supply position.

- The members operate the resources within an environment which provides the enterprise's opportunities and makes certain demands on its performance. The environment is influenced by consumer behaviour, competitors' position, government and labour constraints, general economic conditions, investment climate and so on. The combination of these environmental characteristics determines what the enterprise must do to survive and prosper.

At any point, the relationships between these variables may be viewed as describing the enterprise's present condition and as a basis for evaluating its future prospects.

The individual manager is always confronted by the so-called dynamic variables. He is always concerned with the relationship between the requirements of the environment in which he operates, the resources available to him, and the demands of the persons with whom he deals.

\section{General Management Functions}

In relating these variables every manager performs the three basic general management functions of:

- defining the scope of the firm's activities (what business is it in) 
- specifying performance criteria for his firm (what standards, policies and procedures will be enforced within the firm)

- procuring and conserving resources and then deploying these among competing demands.

At the lowest level, the manager or foreman is most heavily dependent on his technical abilities. As he rises to middle management ranks, his technical skill may increase, but it becomes relatively less important than his ability to work effectively with others. At the top management levels his ability to view the enterprise as a whole is a major strategic requirement. To achieve this successfully the manager must be 'an analyst of conditions affecting his unit, a procurer and allocator of the resources to be used by his unit; and a diagnostician of the interpersonal relationships, values and norms within his unit'. ${ }^{4, p .51}$

The general management functions can be broken down into seven policy commitments or strategic variables. These variables relate the enterprise to its external environment, or, much more simply, they indicate how the business actually conducts its affairs, and a regular analysis of these is vital if the survival and development of the enterprise are to be assured.

The seven policy commitments or strategic variables may be summarized as follows:

- Product policy - the design, specifications, characteristics and mix of products offered.

- Customer policy - the specific types and characteristics of customers to whom products are offered.

- Distribution and promotion policy - the manner in which the products are moved from the supplier to the final consumer and how prospective users are informed and encouraged to purchase.

- Competitive emphasis - what the enterprise can do better than anyone else.

- Pricing policy - what to charge for the various products or services offered.

- Investment policy - funds allocation and capital budgeting.

- Financing policy - where and how to obtain capital for the enterprise.

The manipulation of these variables to their optimum capacities will ensure for the management a desired growth rate for the total enterprise, a desired market penetration, a desired level of profitability, and a desired life span of the firm. Whereas the strategic variables give the enterprise its direction, the operating variables provide the necessary controls for the enterprise. Not only these strategic postures conceming the external environment are important in the management of the total enterprise, but of equal necessity is the internal efficiency of the enterprise, that is the degree to which the enterprise is able to maintain high internal performance levels.

The relevant internal operating variables are the delegation of authority, responsibility and accountability; the formulation and implementation of systems, policies, rules and procedures which govern behaviour; the measurement of the performance of individuals, groups, departments and divisions and of the total enterprise; and, lastly, the representation of the objectives and values of the enterprise to employees and community.
These basic operating variables determine the organization's performance levels. When the structure, standards, and evaluation procedures of the enterprise are clearly defined, it can be regarded as being in control of itself.

\section{Conclusion}

The objective of total enterprise management is to strategically plan, guide and control the firm in its totality. But it is the duty of top management to deal simultaneously with both the strategic and operating variables affecting total corporate performance. The formulation of a strategy and its implementation must not be seen as distinct functions which must be kept apart. Total enterprise management goes further than this: strategy formulation need not be the exclusive prerogative of top management, nor the implementation of strategy the responsibility of subordinate managers. Top management must assure that planned strategies are compatible with the capabilities and motivation of the enterprise's personnel.

Katz's ${ }^{4 . p .}{ }^{60}$ comments on the role of commitment and competence in the management of the total enterprise pinpoint the essentials of this approach. He takes the view that the true test of the manager lies in his ability to respond to his people in such a way that he encourages competence and commitment by:

- establishing a strategy and a set of limits and standards which are acceptable and meaningful to those people;

- deploying resources, measuring performance and administering rewards and punishments in relation to that strategy; and

- assuring that the strategy fits the requirements of the environment, the available resources of the unit, and the competences and commitments of the people.

How these tasks are performed will determine the survival capacity and developmental capability of each unit and of the total enterprise.

\section{References}

1 CYERT, M. \& G. March 1963. A behavioural theory of the firm. Englewood Cliffs, Prentice-Hall, New Jersey.

2 VON NEUMANN, J. \& O. MORGENSTERN 1953. Theory of games and economic behaviour. Princeton University Press, Princeton.

3 BEISHLINE, J. R. 1963. Military management for national defence. Englewood Cliffs, Prentice-Hall, New Jersey.

4 KATZ, R. L. 1970. Management of the total enterprise. Englewood Cliffs, Prentice-Hall, New Jersey. 